\title{
Research Universities in Developing and Middle-Income Countries KAREN MACGREGOR
}

Karen MacGregor is coordinating editor of University World News, from which this article is reprinted. E-mail: editors@iafrica.com. All quotations in this article are from Philip G. Altbach, "Advancing the National and Global Knowledge Economy: The Role of Research Universities," Studies in Higher Education, 38 (April, 2013).

Research universities in low and middle-income countries have crucial roles to play in developing differentiated and effective academic systems and in making it possible for their countries to join the global knowledge society and compete in sophisticated knowledge economies, according to Philip G. Altbach, research professor and director of the Center for International Higher Education at Boston College in the United States.

While research universities in the developing world have not yet achieved the top levels of global rankings, they are "extraordinarily important" in their countries and regions-and are steadily improving their reputations and competitiveness on the international stage-wrote Altbach in an article titled "Advancing the National and Global Knowledge Economy: The Role of Research Universities in Developing Countries": "A key point is that research universities around the world are part of an active community of institutions that share values, foci, and mission." 
Altbach's article was published in a special issue of the journal Studies in Higher Education dedicated to disseminating key concepts arising out of an investigation into higher education's knowledge structure, in a collaboration between the Center for International Higher Education and the Organization for Economic Cooperation and Development's Innovation, Higher Education and Research for Development program.

Research universities were defined as academic institutions "committed to the creation and dissemination of knowledge, in a range of disciplines and fields, and featuring the appropriate laboratories, libraries, and other infrastructures that permit teaching and research at the highest possible level." Worldwide, research universities played complex roles in the academic system, including the core mission of research production and training students to engage in research.

"The research university is no ivory tower and is relevant to the wider community; much of its research is carried out in collaboration, with funding and sponsorship from nonuniversity sources. The research university is a highly complex and multifaceted institution, serving many societal roles." Research universities worldwide have a great deal in common, "stemming from a specific tradition and serving similar roles," Altbach pointed out. There are national variations, but "synergy of research and teaching is a hallmark."

Knowledge production and dissemination must spread internationally, he argued, and wider dissemination of research capacity throughout the world was imperative.

"The argument can be made that all countries need academic institutions, linked to the global academic system of science and scholarship, so that they can 
understand advanced scientific developments and participate selectively in global science."

Most countries could afford to support at least one university of sufficient quality to participate in international discussions of science and scholarship and conduct research in fields relevant to national development.

\section{All Countries Want World-Class Universities}

Around the world, countries have recognized that research universities are key to the knowledge economy of the 21st century. In the United States and Britain, there was rising concern about the ability to maintain the standards of existing research universities. Germany had allocated resources to some key institutions, and Japan had funded competitive grants to create centers of excellence.

“China has placed emphasis on creating 'world-class' research universities, and India is finally beginning to think about the quality of its mainstream institutions. Similar programs to enhance standards exist in South Korea, Chile, Taiwan, and elsewhere," Altbach wrote.

"Several of Africa's traditionally strong universities are seeking to improve their quality in an effort to achieve research university status, with assistance from external funders; but this process is, in general, behind levels of academic development in other continents."

"Research universities have emerged on the policy agenda in many developing countries, especially larger nations that seek to compete in the global knowledge economy." 


\section{Research Universities AND ACAdemic Systems}

Research universities are a very small and specialized but crucial part of any academic system, Altbach argued. In America there were around 220 research universities in a system of more than 4,000 postsecondary institutions. In the United Kingdom, there were just 25 research universities among 100 universities and 300 postsecondary institutions. "Smaller developing countries have perhaps one research university, and many have none." China was developing around 100 research universities-out of more than 3,000 institutions countrywide as part of its efforts to build world-class institutions.

A clearly differentiated academic system was needed for research universities to flourish, Altbach wrote. A good example was the three-tier California public higher education system, established by the California Master Plan, which has at its pinnacle 10 campuses of the research-oriented University of California, the 23-campus California State University system with around 433,000 students, and a community college system with 3 million students. Funding patterns, missions, and governance differ across the three tiers and state regulation maintained their different missions. "By distributing resources with an ideal of efficiency at its core, the Master Plan also institutionalized a commitment to excellence in its best research universities, such as the University of California, Berkeley."

Clark Kerr, architect of the Master Plan, had a vision of the key characteristics of research universities: internal governance primarily in the hands of professors; key decisions receiving inputs from academics-the concept of shared governance is central; rigorous meritocracy; research intertwined with teaching; academic freedom; and engagement with society. 
Developing countries also needed to clearly differentiate the missions of institutions in the postsecondary system and to organize institutions in a rational way.

“Appropriate patterns of funding, realistic teaching arrangements, administrative arrangements, and other key elements of institutions will need to be organized and then implemented. Ensuring that the rapidly expanding private higher education sector is to some extent integrated into the system will also be necessary," Altbach argued.

"The fact is that few if any developing countries have a differentiated academic system in place; and this central organizational requirement remains a key task." Without an appropriate system, which would vary according to national requirements, research universities could not fully flourish.

"These institutions must be clearly identified and supported. There must be arrangements so that the number of research universities will be sufficiently limited so that funding is available for them and that other resources, such as well-qualified academics, are not spread too thinly."

Altbach explored aspects of academia key to research universitiescommunications and networks, journals, libraries, informal communities of scholars, conferences and professional organizations, the Internet, repositories of knowledge, research universities as critical centers, the globalization of science and scholarship, internationalization and the research university, the dilemma of language and the academic profession. 


\section{Present Circumstances}

"To paraphrase Charles Dickens, these are the best of times and the worst of times for research universities," Altbach wrote. While there was wide recognition of the importance of the research university, international academic connections and research, many countries did not realize the complexity of and resources needed to build and sustain them.

He outlined some of the characteristics of successful research universities:

- Virtually all are a part of a differentiated system, standing at the top of an academic hierarchy and receiving appropriate support for their mission.

- Research universities-except in the United States, Japan, and a small number of church-linked institutions in Latin America-are overwhelmingly public institutions. The private sector can seldom support a research university, although some private institutions are emerging with a research focus-such as in Turkey, India, and Latin America.

- Research universities are most successful in regions with little or no competition from nonuniversity research institutes or with strong ties between the universities and such institutes. The "academy of science" system in countries such as Russia and China and some models of research institutes elsewhere lack connections to universities. Some countries are trying to better integrate research institutes and top universities, in some cases merging them-this would undoubtedly strengthen the universities. 
- Research universities are expensive, requiring more funding than other universities-to attract the best staff and students and to provide the infrastructure necessary for top research and teaching. The "cost per student" is higher than the average across an entire system. Adequate salaries for faculty, well-equipped libraries and laboratories, and scholarships for bright but needy students are examples of the expenditures required.

- Research universities must have adequate and sustained budgets; they cannot succeed on the basis of inadequate funding or severe budgetary fluctuation over time.

- At the same time, research universities have the potential for significant income generation. Students are often willing to pay higher fees because of the prestige attached to a degree from them, quality academic programs, and access to top professors. Research universities also generate intellectual property and discoveries and innovations with value in the marketplace. In some countries, they can generate philanthropic gifts.

- Research universities require physical facilities commensurate with their missions, including expensive libraries and laboratories and sophisticated information technology. The infrastructures of research universities are complex and expensive. Not only do they need to be built but they must also be maintained and periodically upgraded.

- Research universities require autonomy to shape their programs and practices. The balance between autonomy and accountability in developing countries may be complicated. 
- Academic freedom is a requirement for all postsecondary institutions but especially research universities.

\section{CONCLUSION}

Research universities in developing countries are at the top of the academic hierarchy and are central to the success of any modern knowledge-based economy, Altbach concluded. "All developing countries need these institutions to participate in the globalized environment of higher education. Thus, understanding the characteristics of the research university and building the infrastructures and the intellectual environment needed for successful research universities is a top priority." 